\title{
TINGKAT FLUOR DALAM AIR MINUM DAN PENGOBATAN FLUOROSIS BERDASARKAN INDEKS THYLSTRUP FEJERSKOV
}

\author{
Putu Yetty Nugraha ${ }^{1}$, Ayu Resitha Darmi ${ }^{2}$ \\ ${ }^{1}$ Bagian Ilmu Kedokteran Gigi Anak, Fakultas Kedokteran Gigi Universitas Mahasaraswati Denpasar \\ ${ }^{2}$ Mahasiswa Tingkat Sarjana, Fakultas Kedokteran Gigi Universitas Mahasaraswati Denpasar \\ e-mail: putuyetty@gmail.com
}

\begin{abstract}
Fluorosis is teeth disorder a kind of enamel hypoplastic that is defect on the enamel that result in changes on the teeth form, it is caused by excessive fluoride intake during tooth development. Fluorosis could discoloration on the enamel that varied from opaque white spots upto brown so that disrupting of the sufferrer dental esthetic. These study aims to trace the literature on fluor content limit in drinking water which can begin the fluorosis. As well as elaborate various types of fluorosis treatment which appropriate with appropriate classification of Thylstrup Fejerskov Index (TFI) on the child's teeth. Writing method have been used was descriptive method. The results of the literature search, limit of the levels of fluoride in drinking water could begin the fluorosis was 1.3 ppm. Classification fluorosis according to Thylstrup Fejerskov Index (TFI) was organized into 10 classes with scores ranging from 0 upto 9 for each grade of enamel change. Score TF 1 upto TF 3 was a kind of mild fluorosis, TF 4 upto TF 6 was moderat fluorosis, and TF 7 upto TF 9 fluorosis was a kind of heavy. Fluorosis treatments that can be used was microabrasion email, bleaching, veneers and jacket crowns as according to the type of fluorosis. Controlling of the fluoride intake for the children under 8 years is very important to prevent fluorosis but if there has been dental fluorosis hence will be needed a treatment to restore the aesthetic and self-confidence in children.
\end{abstract}

Keywords: Levels of Fluoride, Fluorosis Treatment

\section{PENDAHULUAN}

Kebutuhan estetik gigi masyarakat masa kini semakin meningkat. Masyarakat lebih mengenal kedokteran gigi estetik melalui berbagai media dan iklan sehingga menimbulkan minat orang tua untuk melakukan perawatan pada gigi anak mereka apabila terjadi perubahan warna gigi yang dapat mempengaruhi psikologis anak. Pada tahun 1901 seorang dokter gigi Amerika, Dr. F. McKay menemukan kasus email berbintik (mottled enamel) pada kebanyakan pasiennya. Baru sekitar tahun 1930-an diketahui penyebab timbulnya bintik tersebut adalah kadar fluor air minum yang berlebihan yaitu lebih dari $2 \mathrm{mg}$ fluor per liter. Istilah mottled enamel digunakan untuk menggambarkan beberapa gejala dan akibat dari fluorosis gigi. Secara umum, fluorosis merupakan suatu kelainan gigi sejenis hipoplasia email yaitu defek email yang mengakibatkan perubahan bentuk gigi dan warna email mulai dari bintik buram hingga cokelat yang disebabkan oleh asupan fluor yang berlebihan, baik secara sistemik maupun lokal. Fluorosis gigi sering terjadi secara endemik, sekitar $40 \%$ kasus fluorosis gigi disebabkan oleh fluoridasi air minum..$^{\mathbf{1}}$

Fluorosis gigi lebih rentan terjadi pada anak yang mengkonsumsi fluor berlebih selama 20 atau 30 bulan antara usia 1 tahun sampai 4 tahun. Anak yang berusia di atas 8 tahun, tidak lagi beresiko mengalami fluorosis gigi karena mineralisasi gigi insisif sulung berlangsung saat usia 24 bulan, dan sebelum usia 6 tahun untuk molar kedua dan premolar gigi permanen. ${ }^{3,4}$

Mengontrol asupan fluor adalah pencegahan terbaik untuk terjadinya fluorosis gigi. Maka itu, penting bagi dokter gigi untuk mengetahui batas kadar fluor dalam air minum yang dapat memulai terjadinya fluorosis sehingga nantinya dapat diinformasikan kepada orang tua guna mengurangi prevalensi fluorosis gigi anak. Pada anak yang telah mengalami fluorosis gigi, seorang dokter gigi juga membutuhkan pengetahuan tentang jenis perawatan yang dapat digunakan pada fluorosis gigi anak. Kriteria klasifikasi fluorosis gigi yang dikembangkan oleh Thylstrup Fejerskov Indeks (TFI) sangat tepat untuk menentukan jenis perawatan berdasarkan aspek biologis dari fluorosis gigi sehingga perawatan dapat dilaksanakan dengan baik dan mengembalikan rasa percaya diri pada anak. ${ }^{4}$ Masalah yang timbul yaitu berapa batas kadar fluor dalam air minum yang dapat memulai terjadinya fluorosis dan perawatan apa saja yang dilakukan pada gigi anak yang telah mengalami fluorosis berdasarkan klasifikasi Thylstrup Fejerskov Indeks (TFI). Penulisan ini bertujuan untuk menelusuri kepustakaan mengenai batas kadar fluor dalam air minum yang dapat memulai terjadinya fluorosis, jenis perawatan fluorosis, dan perawatan fluorosis yang sesuai dengan klasifikasi Thylstrup Ferjerskov Indeks (TFI) pada gigi anak.

\section{FLUOROSIS}

Fluorosis adalah hipomineralisasi email yang disebabkan retensi protein amelogenin oleh fluor sehingga email tidak mengalami maturasi menyebabkan permukaan luar subsurface berporus. Fluorosis gigi mengakibatkan defek kualitatif email yang dihasilkan oleh peningkatan konsentrasi fluor pada microenvironment sel ameloblas selama masa pembentukan dan perkembangan gigi. Pada fluorosis jenis berat dapat terjadi defek kuantitatif pada email. ${ }^{2 \cdot 3}$ 
Fluorosis gigi bisa disebabkan oleh dosis tunggal yang tinggi, dosis rendah yang berulang kali, atau kontak dengan zat berkadar fluor rendah secara terus menerus. ${ }^{4}$ Keparahan fluorosis gigi tergantung kapan dan berapa lama paparan fluor terjadi, respon individu, berat badan, tingkat aktivitas fisik, faktor gizi dan pertumbuhan tulang menunjukan bahwa dengan dosis yang sama dapat menyebabkan berbagai tingkat keparahan fluorosis gigi. Faktor lain yang dapat meningkatkan kerentanan individu untuk fluorosis gigi adalah tingginya asupan fluor, malnutrisi, dan insufisiensi ginjal. ${ }^{13}$ Fluorosis dapat dicegah dengan mengontrol jumlah asupan fluor yang dikonsumsi anak-anak sampai usia 6 tahun. Berbagai sumber fluor antara lain fluoridasi air minum, tablet fluor, obat tetes fluor, topikal aplikasi fluor, dan pasta gigi fluor. ${ }^{13}$ Berdasarkan penelitian Dean, peningkatan fluorosis yang diakibatkan oleh fluoridasi air minum tampak signifikan apabila kadar fluor dalam air minum di atas 1 ppm. ${ }^{5}$ Tingkat optimal fluor untuk persediaan air masyarakat adalah sekitar 0,7 ppm sampai 1,2 ppm. ${ }^{1}$ Sehingga kadar fluor yang dapat memulai terjadinya fluorosis gigi adalah 1,3 ppm.

Tablet fluor yang sering digunakan terdiri dari senyawa natrium fluoride. Dibawah ini merupakan tabel dosis suplemen fluor harian. ${ }^{6}$

Tabel 1. Dosis suplemen fluor yang dianjurkan oleh The American Dental Asociation tahun 1994. ${ }^{6}$

\begin{tabular}{|l|l|l|l|}
\hline \multirow{2}{*}{ Umur (tahun) } & \multicolumn{3}{|l|}{ Konsentrasi fluor di dalam air minum $(\mathrm{ppm})^{\mathbf{*}}$} \\
\cline { 2 - 4 } & $<0,3$ & $0,3-0,6$ & $>0,6$ \\
\hline Lahir-6 bulan & - & - & - \\
\hline 6 bulan-3 tahun & $\begin{array}{l}0,25 \mathrm{mg} \mathrm{F} / \\
\text { hori }\end{array}$ & $\begin{array}{l}0,0 \mathrm{mg} \\
\text { F/hari }\end{array}$ & $0,0 \mathrm{mg} \mathrm{F} / \mathrm{hari}$ \\
\hline 3 tahun-6 tahun & $0,50 \mathrm{mg} \mathrm{F} / \mathrm{hari}$ & $\begin{array}{l}0,25 \mathrm{mg} \\
\text { F/hari }\end{array}$ & $0,0 \mathrm{mg} \mathrm{F} / \mathrm{hari}$ \\
\hline $\begin{array}{l}\text { 6 tahun-16 } \\
\text { tahun }\end{array}$ & $1,0 \mathrm{mg} \mathrm{F} / \mathrm{hari}$ & $\begin{array}{l}0,50 \mathrm{mg} \\
\text { F/hari }\end{array}$ & $0,0 \mathrm{mgF} / \mathrm{hari}$ \\
\hline
\end{tabular}

Fluor dalam bentuk obat tetes biasanya dicampur dengan vitamin. Penggunaan fluor dalam obat tetes adalah untuk bayi dan balita. Suplemen fluor seperti tablet ataupun tetes fluor direkomendasikan untuk anak yang hidup di daerah kekurangan fluor. Di daerah fluoridasi air minum, resiko fluorosis gigi karena menggunakan suplemen fluor hampir 4 kali lebih tinggi daripada daerah yang tidak menggunakan fluoridasi air minum. ${ }^{1,3}$ Berbagai macam bentuk fluor yang digunakan pada topikal aplikasi yaitu pasta fluor konsentrasi tinggi $\left(\mathrm{SnF}_{2} \mathbf{1 0 \%}\right)$ dan larutan fluor $\mathrm{SnF}_{2} \mathbf{1 0 \%}$, larutan fluor $\mathrm{SnF}_{2} 20 \%$, dan fluor dalam bentuk gel. ${ }^{1}$ Beberapa saran harus diterapkan guna mencegah atau mengurangi potensi konsumsi fluor yaitu dengan mengurangi konsentrasi fluor dalam produk dan pengurangan waktu aplikasi, mempertahankan dental chair dalam posisi vertikal sehingga pasien tetap duduk guna mencegah fluor mengalir dan tertelan, selalu mengunakan saliva ejector, menghilangkan kelebihan fluor dengan kain kasa, dan meminta pasien untuk meludah sebanyak mungkin setelah aplikasi fluor. Hal tersebut merupakan metode yang sesuai untuk anak di atas usia 3 tahun. ${ }^{3}$
Kebanyakan pasta gigi yang kini dijual di seluruh dunia berisi fluor dalam bentuk natrium monofluorophosfat (NaMFP) karena kompatibel dengan zat abrasif yang digunakan. Pada anak pra sekolah pemakaiannya harus diawasi karena pada umumnya mereka masih belum mampu berkumur dengan baik sehingga sebagian pasta gigi yang digunakan dapat tertelan. Pada anak pra sekolah yang telah mengkonsumsi tablet fluor, orang tua harus dihimbau agar membatasi penggunaan pasta gigi fluor sebatas 0,3 gram yang besarnya kira-kira sama dengan ukuran kacang polong kecil sebanyak 2 kali sehari. ${ }^{4}$

Total asupan fluor per hari bervariasi antara 0,2 mg untuk bayi sampai 5,0 mg pada orang dewasa. Fluor yang dikonsumsi $90 \%$ diserap melalui saluran pencernaan dan $10 \%$ diekskresikan melalui feces sedangkan yang diabsorbsi diekskresikan melalui ginjal. ${ }^{6}$ Mekanisme fluor dosis tinggi dalam pembentukan email memiliki berbagai akibat-akibat yang merugikan dalam tahap pembentukan email, antara lain: 1. Adanya perubahan produksi atau komposisi matriks email selama fase sekretori ameloblas; 2. Gangguan pada proses kalsifikasi awal disebabkan oleh perubahan mekanisme transportasi ion; 3. Gangguan fungsi ameloblas, sehingga mempengaruhi berkurangnya protein dan air dari kalsifikasi email selama fase maturasi; 4. Gangguan pertumbuhan nukleasi dan kristal dalam semua tahap pembentukan email, sehingga terjadi berbagai tingkat porositas email (hipomineralisasi). ${ }^{7}$

Proses terjadinya fluorosis gigi diawali dengan hipomineralisasi email karena terlalu banyak menelan ion fluor dari air minum yaitu lebih dari 2 ppm selama periode mineralisasi gigi. Terjadi keracunan pada ameloblas sehingga merubah bentuk email. Ketika gigi erupsi, terlihat white spot atau daerah-daerah yang kemudian akan terwarnai oleh pigmen oral sehingga tampak berwarna cokelat muda atau cokelat tua. Dampak yang lebih parah dari kelebihan fluor selama perkembangan gigi adalah terbentuknya retakan atau lubang-lubang sehingga pewarnaan pada gigi berpusat di tempat ini. ${ }^{1}$

Sistem klasifikasi Thylstrup Fejerskov Indeks (TFI) dibuat untuk mengukur derajat keparahan fluorosis gigi. Berdasarkan deskripsi berbagai tingkat keparahan fluorosis gigi dengan melihat perubahan email seperti yang diamati pada suatu permukaan gigi maka dapat disusun menjadi 10 kelas dimana skor berkisar dari 0 (normal) sampai 9 ditetapkan bagi setiap tingkat perubahan email (lihat tabel 2). 
Tabel 2. Klasifikasi Thylstrup Fejerskov Indeks. ${ }^{7}$

\begin{tabular}{|c|c|}
\hline Skor & \\
\hline 0 & $\begin{array}{l}\text { Translusensi normal, email berwarna putih krem } \\
\text { dan mengkilap meskipun permukaan gigi sudah } \\
\text { dibersihkan dan dikeringkan. }\end{array}$ \\
\hline 1 & $\begin{array}{l}\text { Terlihat garis-garis kecil putih opak berjalan } \\
\text { menyilang pada permukaan gigi. Garis-garis } \\
\text { tersebut terdapat di seluruh permukaan gigi. } \\
\text { Letak garis ini sesuai dengan letak perikymata. } \\
\text { Pada beberapa kasus, mungkin terlihat adanya } \\
\text { sedikit snow capping pada cusp/insisal edge. }\end{array}$ \\
\hline 2 & $\begin{array}{l}\text { Garis putih opak lebih menonjol, dan seringkali } \\
\text { bergabung kemudian membentuk daerah awan } \\
\text { kecil, yang menyebar di seluruh permukaan } \\
\text { gigi. Biasanya terdapat snow capping pada } \\
\text { insisal edge dan puncak cusp. }\end{array}$ \\
\hline 3 & $\begin{array}{l}\text { Nampak gabungan garis-garis putih dan muncul } \\
\text { daerah awan opak yang tersebar pada beberapa } \\
\text { bagian permukaan gigi. Di antara daerah awan } \\
\text { tersebut dapat juga terlihat garis-garis putih. }\end{array}$ \\
\hline 4 & $\begin{array}{l}\text { Pada seluruh permukaan terlihat adanya opasitas } \\
\text { atau nampak putih seperti kapur (chalky white). } \\
\text { Bagian dari permukaan yang atrisi atau aus, } \\
\text { nampak kurang terserang. }\end{array}$ \\
\hline 5 & $\begin{array}{l}\text { Seluruh permukaan tampak opak, dan terdapat } \\
\text { pit-pit bulat (hilangnya pusat dari email terluar) } \\
\text { yang kurang dari } 2 \text { milimeter. }\end{array}$ \\
\hline 6 & $\begin{array}{l}\text { Pit-pit kecil seringkali terlihat bergabung pada } \\
\text { email yang opak membentuk pita yang lebarnya } \\
\text { dalam arah vertikal kurang dari } 2 \text { milimeter. } \\
\text { Pada klas ini juga terdapat kasus di mana cuspal } \\
\text { rim dari email fasial telah terlepas dan terjadi } \\
\text { pengurang dimensi vertikal kurang dari } 2 \\
\text { milimeter. }\end{array}$ \\
\hline 7 & $\begin{array}{l}\text { Email bagian terluar terlepas, sehingga } \\
\text { membentuk daerah yang tidak teratur pada } \\
\text { permukaan gigi. Permukaan yang terserang } \\
\text { lebih dari setengah. Email utuh yang tersisa, } \\
\text { opak. }\end{array}$ \\
\hline 8 & $\begin{array}{l}\text { Hilangnya email terluar melibatkan lebih dari } \\
\text { setengah email. Email utuh yang tersisa opak. }\end{array}$ \\
\hline 9 & $\begin{array}{l}\text { Hilangnya sebagian besar email terluar yang } \\
\text { mengakibatkan perubahan bentuk anatomis pada } \\
\text { permukaan gigi. Sering dijumpai adanya rim } \\
\text { enamel yang opak di servikal. }\end{array}$ \\
\hline
\end{tabular}

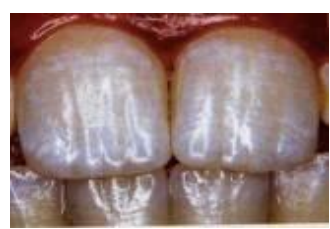

Gambar 1. Contoh fluorosis gigi dengan skor TF 1.7

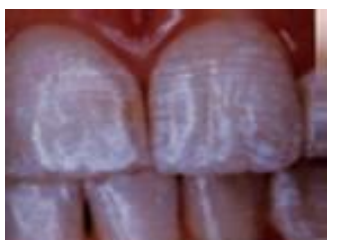

Gambar 2. Contoh fluorosis gigi dengan skor TF $2 .^{7}$

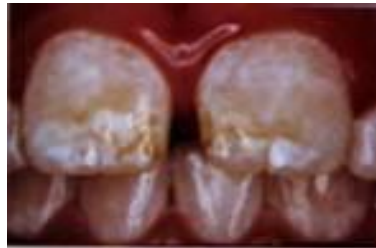

Gambar 3. Contoh fluorosis gigi dengan skor TF 3. ${ }^{14}$

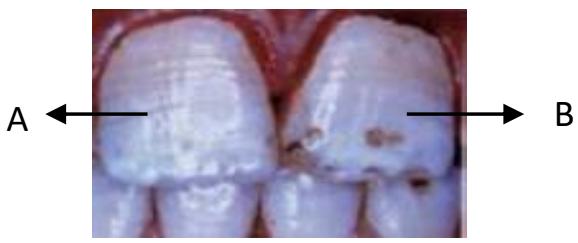

Gambar 4. Contoh fluorosis gigi dengan skor TF 4 (A) dan skor TF 5(B). ${ }^{14}$

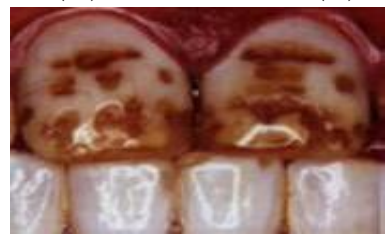

Gambar 5. Contoh gigi dengan skor TF $7 .^{14}$

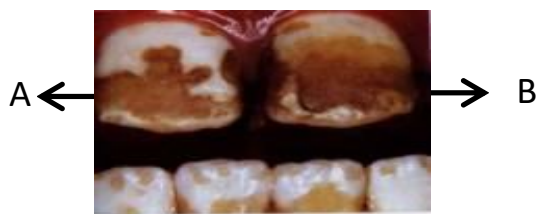

Gambar 6. Contoh gigi dengan skor TF 8 (A) dan TF 9 (B). ${ }^{14}$

\section{PERAWATAN FLUOROSIS PADA GIGI ANAK}

1. Mikroabrasi email.

Teknik mikroabrasi email merupakan suatu cara untuk menghilangkan struktur email gigi dengan menggunakan bahan kimia yang dapat melarutkan permukaan email gigi secara selektif menggunakan asam hidroklorit dengan konsentrasi $11 \%$ dan partikel silicone carbide dalam bentuk pasta untuk meningkatkan daya abrasif (lihat gambar 13). ${ }^{3}$

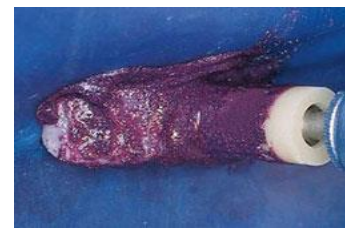

Gambar 7. Aplikasi pasta menggunakan instrumen putar yang dilakukan dalam prosedur mikroabrasi email. ${ }^{17}$

2. Bleaching

Bleaching adalah suatu cara pemutihan kembali gigi yang berubah warna sampai mendekati warna gigi asli dengan proses perbaikan secara kimiawi menggunakan bahan reduksi atau oksidasi berkekuatan tinggi guna mengembalikan estetik penderita. Kasus fluorosis (mottled enamel) dapat ditanggulangi menggunakan metode bleaching ekstrakorona pada gigi yang masih vital. Terdapat 2 
teknik bleaching ekstrakorona yang dapat digunakan untuk perawatan fluorosis yaitu in office bleaching yang dilaksanakn secara langsung di klinik dokter gigi menggunakan material pemutih hydrogen peroxide $\left(\mathrm{H}_{1} 2 \mathrm{O}_{1} 2\right) 35 \%$ yang disebut juga superoxol dan home bleaching yang umum digunakan untuk perubahan warna ringan dan pada dasarnya dianjurkan bagi teknik pemutihan yang bisa dilakukan sendiri oleh pasien di rumah menggunakan carbamide peroxide $10 \%$ (lihat gambar14, 15, dan 16)..$^{0^{0} 11}$

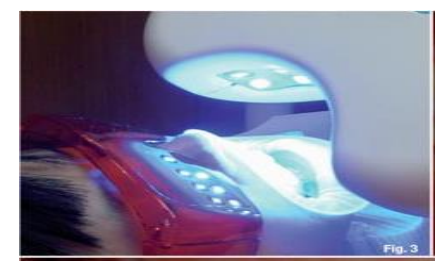

Gambar 8. Aktivasi in office bleaching menggunakan sinar. ${ }^{12}$

\section{Veneer}

Veneer merupakan suatu bentuk restorasi berupa suatu lapisan yang ditempelkan ke bagian labial gigi depan. Bahan yang digunakan untuk pembuatan veneer dapat berupa resin komposit atau porselen. (lihat gambar 17 dan 18). ${ }^{16}$

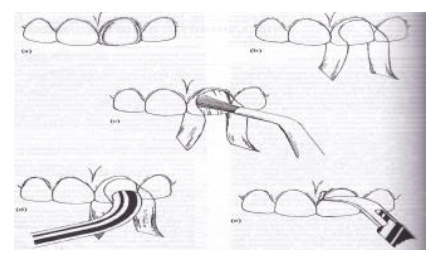

Gambar 9. Ilustrasi teknik pembuatan veneer labial resin komposit. ${ }^{23}$

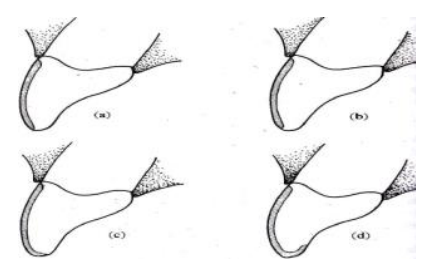

Gambar 10. Contoh ilustrasi preparasi insisal edge untuk veneer porselen. ${ }^{17}$

\section{Mahkota Jaket}

Mahkota jaket adalah restorasi yang mengelilingi seluruh atau sebagian struktur gigi yang tersisa. Mahkota jaket diindikasikan untuk sisa struktur gigi yang lemah sehingga tidak dapat menahan tekanan. Jika keadaan hipoplasia parah dan mengenai permukaan gigi, mahkota jaket merupakan restorasi yang paling tepat. Untuk anak, dianjurkan preparasi gigi yang minimal, tanpa bahu, untuk menghindari kerusakan pulpa. Jenisnya meliputi mahkota jaket akrilik untuk gigi anterior, mahkota stainless steel untuk molar, dan cast veneer untuk premolar. ${ }^{17}$

Fluorosis mengakibatkan gangguan estetik yang harus diatasi dengan melakukan berbagai macam perawatan sesuai klasifikasi tingkat keparahan fluorosis.
Sebelum melaksanakan perawatan sebaiknya dilakukan diagnosa yang adekuat dengan pemeriksaan, pembersihan, dan pengeringan di bawah cahaya yang baik. Perawatan fluorosis pada umumnya didasarkan pada pertimbangan nilai estetik, pengembalian fungsi serta pertimbangan ekonomi pada pasien penderita fluorosis., ${ }^{2,3}$

Berdasarkan Thylstrup Fejerskov Indeks (TFI), gigi dengan skor TF 1 sampai TF 3 termasuk dalam fluorosis jenis ringan dapat dilakukan perawatan dengan teknik mikroabrasi email pada TF 1 dan TF 2, dan teknik bleaching pada TF $3 .^{3}$

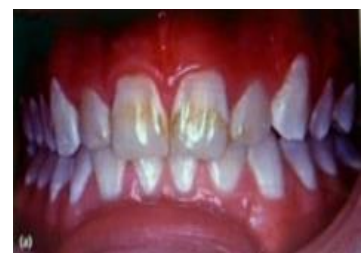

A

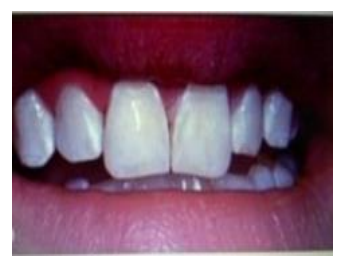

B
Gambar 11. Fluorosis jenis ringan pada permukaan email gigi anak perempuan berusia 14 tahun, sebelum

(A) dan sesudah (B) perawatan mikroabrasi email. ${ }^{18}$

Fluorosis gigi dengan skor TF 4 sampai TF 6 termasuk dalam fluorosis jenis sedang (moderate) dapat dilakukan perawatan dengan teknik bleaching pada TF 4, dan teknik veneer untuk TF 5 dan TF $6 .^{3}$
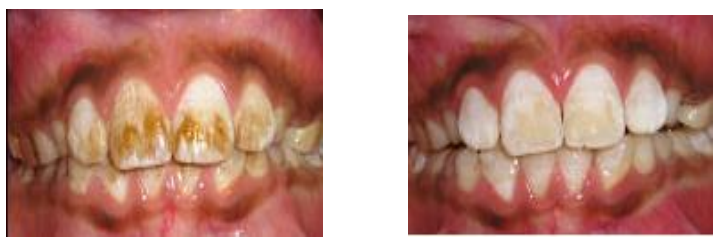

Gambar 12. Fluorosis jenis sedang sebelum (A) dan sesudah (B) perawatan bleaching. ${ }^{19}$
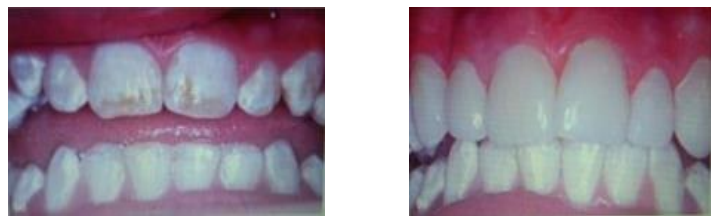

Gambar 13. Fluorosis jenis moderate sebelum dan sesudah perawatan veneer porselen pada anak perempuan berusia 9 tahun. ${ }^{18}$

Fluorosis gigi dengan skor TF 7 sampai TF 9 termasuk dalam fluorosis jenis berat perawatan dapat dilakukan dengan teknik veneer pada TF 7 dan mahkota jaket untuk TF 8 sampai TF 9.3

\section{PEMBAHASAN}

Fluor dosis tinggi menyebabkan porositas email, pada saat gigi erupsi timbul white spot, kuning atau coklat dan semakin lama muncul retakan atau lubang sehingga pewarnaan berpusat di tempat ini. Keparahan fluorosis gigi tergantung kapan dan berapa lama paparan 
fluor terjadi, respon individu, berat badan, tingkat aktifitas fisik, faktor gizi, dan pertumbuhan tulang. Kadar optimal fluor dalam air minum adalah 0,7 ppm sampai 1,2 ppm, sehingga apabila kadar fluor dalam air minum 1,3 ppm maka akan memulai terjadinya fluorosis gigi. Klasifikasi fluorosis berdasarkan Thylstrup Fejerskov Indeks dari skor 0 sampai 9 dimana keparahannya tergantung pada usia anak dan banyaknya fluor yang dikonsumsi. ${ }^{1 / 3 / 5}$

Mikroabrasi email diindikasikan sebagai perawatan awal pada gigi sulung maupun permanen muda karena perawatan ini menggunakan pasta silicone carbide yang mengerosi email secara selektif hanya pada daerah yang mengalami perubahan warna tanpa menimbulkan iritasi pada pulpa, memberikan hasil perbaikan estetik yang sangat baik, dan tidak menimbulkan trauma psikologis pada anak karena suara bor, rasa sakit ataupun suhu yang panas pada saat perawatan. $^{2}$

Bleaching dilakukan sebagai perawatan lanjutan apabila perawatan mikroabrasi tidak memberikan perbaikan estetik atau dikhawatirkan akan sangat mengurangi ketebalan email pada pitting yang dalam apabila dilakukan mikroabrasi email, meningkatkan sensitivitas, dan menimbulkan iritasi pada pulpa. Perawatan bleaching menggunakan bahan kimiawi untuk memutihkan gigi dan sedikit pengasahan, sehingga tetap menjaga ketebalan email. ${ }^{20}$

Veneer atau pelapisan menggunakan bahan resin komposit atau porselen dapat dilakukan sesuai dengan usia anak, agar diketahui pulpanya masih lebar atau tidak supaya memungkinkan adanya preparasi lebih pada penggunaan veneer porselen. Perawatan ini diindikasikan untuk fluorosis gigi yang telah kehilangan email cukup banyak sehingga perawatan mikroabrasi dan bleaching semakin mengurangi ketebalan email, mengiritasi pulpa, dan rasa panas saat perawatan bleaching dapat menimbulkan trauma psikologis pada anak. Maka itu diperlukan pelapisan atau veneer untuk mengembalikan estetika gigi tanpa menimbulkan efek buruk bagi kesehatan gigi. ${ }^{16}$

Mahkota jaket diindikasikan bagi gigi dengan fluorosis parah yang telah kehilangan sebagian besar email gigi. Email yang tersisa hanya di bagian servikal sehingga tidak mampu menahan tekanan kunyah dan sangat mengganggu estetika. Pada tahap ini apabila dilakukan perawatan mikroabrasi dan bleaching dapat mengiritasi jaringan pulpa bahkan timbul nekrose pulpa sedangkan perawatan veneer tidak dapat dilakukan karena sisa email tidak memadai untuk mendapatkan retensi yang cukup. Maka itu, diperlukan perawatan mahkota jaket untuk melindungi jaringan gigi yang tersisa, memperbaiki fungsi kunyah, dan mengembalikan estetika gigi. ${ }^{17}$

\section{SIMPULAN DAN SARAN}

Fluorosis merupakan keadaan irreversible sejenis hipoplasia email akibat asupan fluor yang berlebihan sehingga terjadi hipomineralisasi pada tahap maturasi yang mengakibatkan defek kualitatif atau kuantitatif pada email. Batas kadar fluor dalam air minum yang dapat memulai terjadinya fluorosis gigi adalah $1,3 \mathrm{ppm}$. Klasifikasi fluorosis menurut Thylstrup Fejerskov Indeks (TFI) dibagi menjadi 10 kelas dari skor 0 sampai 9 sesuai perubahan email. Perawatan fluorosis meliputi mikroabrasi email, bleaching, veneer, dan mahkota jaket. Mengontrol asupan fluor anak dibawah usia 8 tahun merupakan pencegahan terbaik untuk fluorosis, akan tetapi apabila telah terjadi fluorosis gigi maka diperlukan perawatan guna mengembalikan estetika dan rasa percaya diri pada anak.

Banyak jenis diskolorasi gigi yang dapat mengganggu estetik gigi anak. Salah satunya adalah fluorosis gigi yang seringkali terjadi secara endemik tanpa diketahui penyebabnya oleh penderita. Maka itu, untuk memelihara dan meningkatkan estetik gigi anak hendaknya selalu memperdalam dan memperluas pengetahuan tentang kelainan gigi yang mengganggu estetika seperti fluorosis gigi, selalu menghimbau orangtua tentang dosis aman fluor dalam air minum dan mengawasi anak pra sekolah pada saat menggosok gigi untuk mencegah tertelannya pasta gigi, selalu mengontrol penggunaan tablet fluor, obat tetes, dan topikal aplikasi pada klinik dokter gigi guna mengurangi resiko fluorosis gigi dan bagi dokter gigi untuk selalu mengikuti pelatihan kedokteran gigi mengenai perawatan estetika untuk menambah keterampilan perawatan gigi anak yang mengalami fluorosis.

\section{DAFTAR PUSTAKA}

1. Putri MH, Herijulianti E, Nurjannah N. Ilmu Pencegahan Penyakit Jaringan Keras dan Jaringan Pendukung Gigi. Jakarta: EGC; 2011.

2. Achmad HM. Penanganan fluorosis pada gigi sulung dengan menggunakan teknik mikroabrasi. Dentofasial 2007; 6(1):42-50.

3. Alvarez dkk. Dental fluorosis : exposure, prevention, and management. Med Oral Patol Oral Cir Bucal 2009;14(2):103-107.

4. Kidd EAM, Bechal SJ. Dasar-Dasar Karies Penyakit dan Penanggulangannya. Ed. ke-2. S Narlan, F Safrida. Jakarta: EGC; 1992.

5. Fejerskov 0, Ekstrand J, Burt BA. Fluoride in Dentistry. Ed. ke-2. Muksgard Copenhagen: ;1996.

6. Sriyono NW. Pengantar Ilmu Kedokteran Gigi Pencegahan. Ed. ke-3. Yogyakarta: Medika Fakultas Kedokteran Gigi UGM; 2009.

7. Messer LB, Mekertichian K. Fluoride Modalities. In: AC Cameron, RP Widmer. Handbook of Pediatric Dentistry. Ed. ke-2. Sidney: Mosby; 2003.

8. Cliath BA. Controlling dental fluorosis. Irreland: Forum on Fluoridation; March 14, 2002.

9. Acosta H. Whitening. Homepage of Lake Myrtle Center for Advanced Dentistry [Online].2012. Available

from:http://www.dracostadmd.com/whitening/. Accessed November 10, 2012.

10. Tarigan R. Perawatan Pulpa Gigi ( Endodonti). Ed. Ke-2. Jakarta: EGC; 2004.

11. Walton RE, Torabinejad M. Prinsip dan Praktek Ilmu endodonsia. Ed. Ke-3 Jakarta: EGC; 2008.

12. Kwon S. Tooth Whitening: A Conservative Approach. Homepage of Dental Tribune. [Online]. 
2009.

Available

from:http://www.dentaltribune.com/articles/content /scope/ specialities/region/international/id/369. Acessed August 8, 2012.

13. Mouawad SA. Wondering About Whitening. Homepage of Mouawad Dental Clinic Where Function MeetsAesthetics. [Online].2011.Available from

dentalclinic.blogspot.com/2011/07/wonderingabout-whitening.html. Acessed December 2, 2012.

14. Kathuria. Instruction of Home Bleaching. Homepage from Teeth Whitening, [Online]. 2005 Available from : Error! Hyperlink reference not valid. December 2, 2012.

15. Ardu S, Stavridakish M, Krejci I. A minimally invasive treatment of severe dental fluorosis. Quintessence International 2007;38 (6):455-458.

16. Inayanti E. Restorasi veneer keramik secara indirek. M.I. Kedokteran Gigi 2008; 23(1): 32-37.
17. Andlaw RJ, Rock WP. Perawatan Gigi Anak. Ed. ke-2, Agus Djaya (penerjemah). Jakarta: Widya Medika;1992

18. Koch G, Poulsen S. Pediatric Dentistry: A Clinical Approach. Homepage google book. [Online]. 2009 Available from :http://books.google.co.id/books?id= pqhzzcjCFH4C\&pg=PA101\&dq=Koch+and+Pouls en+Mild+fluorosis\&hl=id\&sa $=X \& e i=k 3 u b U N i c M c$ PlrAe2rYHIBQ\&ved=0CCgQ6AEwAA\#v=onepag e\&q=Koch\%20and\%20Poulsen\%20Mild\%20fluoro sis\&f=false. Acessed October 1, 2012.

19. Manjunatheswara SD. Pedodontics. Homepage of SDM College of Dental Sciences \& Hospital. [Online]. 2007 Available from :http://www.spandana-alumni.com/sdm/ patientspedo.html. Acessed September 29, 2012.

20. Irmawati, Herawati. Perawatan pemutihan pada gigi anak. Indonesian Journal of Dentistry 2005;12(2):85-88 